\section{Effect of selection response for yield related traits in early and later generations of groundnut (Arachis hypogaea L.)}

\author{
Jignesh H. Kamdar ${ }^{1}$, Mital D. Jasani ${ }^{1}$, Ajay B. C. ${ }^{1}$, Sandip Kumar \\ Bera $^{1^{*}}$ and John J. Georrge ${ }^{2^{*}}$
}

\begin{abstract}
In the present study, the correlation and presence of genetic interactions were studied in the $F_{3}$ and $F_{5}$ generations of two groundnut (Arachis hypogaea L.) crosses. Most of the characters studied were positively skewed and were governed by multiple genes, indicating quantitative inheritance. Variance, skewness, and kurtosis indicate that homozygosity has increased over the generations in both crosses. Cross- $B$ was found to be better than cross- $A$ in providing high-yielding segregants displaying parental diversity. Pod yield per plant and other associated characters, such as plant height, are controlled by complementary action of multiple genes. A shift in correlation coefficients was recorded between the generations, which can be attributed to the difference in gene complementation of linkage blocks and is an indication of the unstable nature of the breeding population. Overall, five lines with superior pod yield were identified, which could be used for varietal development.
\end{abstract}

Keywords: Groundnut, Arachis hypogaea L., skewness, kurtosis, correlation.

\section{INTRODUCTION}

Groundnut (Arachis hypogaea L.) is an important self-pollinated oilseed crop (Kamdar et al. 2017, Kumar et al. 2019). It is an autogamous allotetraploid legume $(2 n=4 x=40)$ comprising the $A$ and $B$ genomes derived from two diploids (Kamdar et al. 2020). Groundnut is cultivated in semi-arid tropical (SAT) regions of the world, covering about 28.5 million hectares and with a total production of 45.95 million tons of pods as of 2018 (Pandey et al. 2020). China, India, Nigeria, and the United States of America (USA) are the leading groundnut producers that account for $\sim 70 \%$ of global peanut production (Bera et al. 2018, Bera et al. 2019). The productivity of groundnut varies from 3500 $\mathrm{kg}$ ha in the USA to $2500 \mathrm{~kg} \mathrm{ha}^{-1}$ in South America, $1600 \mathrm{~kg} \mathrm{ha}^{-1}$ in Asia, and less than $800 \mathrm{~kg} \mathrm{ha}^{-1}$ in Africa (Prasad et al. 2010). In India, the productivity of groundnut (1486 $\mathrm{kg} \mathrm{ha}^{-1}$ ) in comparison to other developing countries is low (Gayathri 2018). This low productivity is attributed to the narrow genetic base of the crop and rainfed cultivation, which renders the crop vulnerable to various biotic and abiotic stresses (Toker and Mutlu 2011). Variability is fundamental for the success of a selection work (Andrade 2019) since, progress in breeding programs depends on the amount of variability available in the population (Vinithashri et al. 2019). Standard measures of variability, namely range, variance, and standard error, were commonly used to assess the variability
Crop Breeding and Applied Biotechnology 20(2): e317320215, 2020 Brazilian Society of Plant Breeding. Printed in Brazil http://dx.doi.org/10.1590/198470332020v20n2a31 70332020v20n2a31

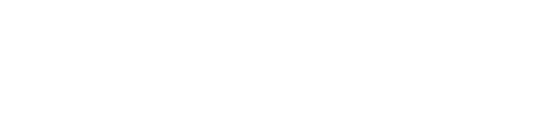


and gene action for desirable traits. Information on the frequency distribution of different traits will help in identifying plants with the desirable expression of a particular trait under selection (Dinesh et al. 2018). Breeding for high yield is the main objective of any crop improvement program (Woyann et al. 2019). Since yield is polygenically controlled and highly influenced by the environment (Santos et al. 2014), selection based on yield alone may not be effective. Hence, improvement in yield could be attained by affecting indirect selection through component characters (Luz et al. 2011) that are highly heritable and show a strong correlation with yield. The present study was aimed at studying the genetics of different traits in association with yield and its component traits using third and fourth degree statistics in early and later generations of two different groundnut crosses.

\section{MATERIAL AND METHODS}

The study was conducted at the Indian Council of Agricultural Research Directorate of Groundnut Research (ICARDGR), Gujarat, India. ICAR-DGR is situated between $21.49^{\circ} \mathrm{N}$ latitude and $70.44^{\circ} \mathrm{E}$ longitude at an elevation of $107 \mathrm{~m}$ above sea level. The material used for this study consisted of $F_{3}$ and $F_{5}$ generations from two crosses of groundnut, namely GG7 $\times$ Sunoleic95R (Cross-A) and TKG19A × SunOleic95R (Cross-B). A total of 189 progenies, 25 of $F_{3}$ and 164 of $\mathrm{F}_{5}$, were developed using the single seed descent (SSD) method under field conditions during kharif (monsoon) seasons in 2018 and 2019, and standard crop management practices were followed to grow a healthy crop. A common dose of $40 \mathrm{~kg} \mathrm{~N}, 50 \mathrm{~kg} \mathrm{P}, 50 \mathrm{~kg} \mathrm{~K} \mathrm{O}$, and $20 \mathrm{~kg} \mathrm{~S}$ per hectare was applied at $50 \%$ as basal and $50 \%$ at 40 days after planting using ammonium sulfate, diammonium phosphate (DAP), muriate of potash, and elemental S. Kernels were treated with carbendazin at $2 \mathrm{~g} \mathrm{~kg}^{-1}$ of seeds before sowing. Pre-emergence weedicide pendimethylin was sprayed at 2-3 $\mathrm{mL} \mathrm{L}^{-1}$ of water immediately after post-sowing irrigation. Weeds in the standing crop were controlled by $3 \mathrm{~mL} \mathrm{~L}^{-1}$ water solution of post-emergence weedicide imazethapyr, and sucking pests were contained by spraying imidacloprid at $2 \mathrm{~mL} \mathrm{~L}^{-1}$ of water. Lifesaving irrigation was applied as required. Each progeny was sown in one line of a $5 \mathrm{~m}$ bed. At maturity, three samples with three plants per sample were collected from each progeny. Observations were recorded on the number of branches per plant, plant height $(\mathrm{cm})$, plant dry weight per plant $(\mathrm{g})$, number of pods per plant, and pod yield per plant $(\mathrm{g})$. The number of branches was counted visually, whereas plant height was measured from the ground level to the tip of the main axis. The plant dry weight was weighed after sun drying and averaged. The total number of pods was counted individually and averaged. The weight of the total number of pods per plant after optimum pod maturity was recorded and expressed in grams.

The association between yield and its associated characters was determined as a simple phenotypic correlation coefficient using an analysis toolkit in Microsoft Excel software. ANOVA, skewness (K3), third degree statistics and kurtosis (K4), and fourth degree statics were estimated using a PAST statistical package (Hammer et al. 2001) to understand the nature of trait distributions.

In addition, the yield of $164 \mathrm{~F}_{5}$ progenies was compared with the best check cultivars JL501 (Spanish bunch), TG37A (Spanish bunch), and GJG32 (Virginia Bunch), grown along the test lines. The habit of all $F_{5}$ progenies was checked randomly by recording the presence of flowers on the main stem. Progeny with flowers present on the main stem was classified as Spanish bunch (SB), while progenies without the flower on the main stem were categorized as Virginia bunch (VB). The $F_{5}$ progeny with higher pod yield per plant than their respective check cultivars were selected for further evaluation. The standard error of the mean (SE), critical difference (CD), and coefficient of variation (CV) were analyzed using the formula described by Jasani et al. (2018).

\section{RESULTS AND DISCUSSION}

Analyses of variance revealed a highly significant difference for all traits, namely the number of branches per plant, plant height, plant dry weight per plant, number of pods per plant, and pod yield per plant, between generations and crosses (Table 1), indicating that adequate variability was found in all the characteristics studied.

The study of distribution using skewness and kurtosis provides information about the nature of gene action and the number of genes controlling the traits (Govintharaj et al. 2018). Positive skewness is associated with complementary gene action, while negative skewness is associated with duplicate (additive $\times$ additive) gene interactions. Kurtosis is negative or close to zero (platykurtic) in the absence of gene interaction, but positive in the presence of gene interaction 
Table 1. Analysis of variance for five quantitative traits in $F_{3}$ and $F_{5}$ progenies of groundnut

\begin{tabular}{|c|c|c|c|c|c|c|c|c|c|c|c|c|c|}
\hline \multirow[b]{2}{*}{$\begin{array}{l}\text { Sources of } \\
\text { variance }\end{array}$} & \multirow[b]{2}{*}{ Crosses } & \multicolumn{2}{|c|}{ df } & \multicolumn{2}{|c|}{$\begin{array}{l}\text { Plant Height } \\
(\mathrm{cm})\end{array}$} & \multicolumn{2}{|c|}{$\begin{array}{c}\text { No. of } \\
\text { Branches }\end{array}$} & \multicolumn{2}{|c|}{$\begin{array}{l}\text { Plant dry } \\
\text { weight (g) }\end{array}$} & \multicolumn{2}{|c|}{$\begin{array}{l}\text { Pod yield per } \\
\text { plant }(\mathrm{g})\end{array}$} & \multicolumn{2}{|c|}{$\begin{array}{c}\text { Number of pods } \\
\text { per plant }\end{array}$} \\
\hline & & $\mathrm{F}_{3}$ & $\mathrm{~F}_{5}$ & $\mathrm{~F}_{3}$ & $\mathrm{~F}_{5}$ & $\mathrm{~F}_{3}$ & $\mathrm{~F}_{5}$ & $\mathrm{~F}_{3}$ & $\mathrm{~F}_{5}$ & $\mathrm{~F}_{3}$ & $\mathrm{~F}_{5}$ & $\mathrm{~F}_{3}$ & $\mathrm{~F}_{5}$ \\
\hline & Cross-B & 2 & 2 & 13.59 & 9.37 & 0.55 & 2.16 & 71.53 & 13.63 & 1.72 & 1.79 & $6.71^{*}$ & 2.90 \\
\hline \multirow[t]{2}{*}{ Genotypes } & Cross-A & 20 & 134 & $42.77^{*}$ & 99.84* & $1.46^{*}$ & $9.78^{*}$ & 194.80* & $142.05^{*}$ & $18.39 *$ & $24.14^{*}$ & $28.13^{*}$ & $48.97^{*}$ \\
\hline & Cross-B & 3 & 28 & $16.98^{*}$ & 167.76* & $2.60 *$ & $5.67^{*}$ & 394.55 & 171.43* & $19.76^{*}$ & $33.55^{*}$ & $29.58^{*}$ & $33.23^{*}$ \\
\hline & Cross-B & 6 & 56 & 3.41 & 10.07 & 0.50 & 0.96 & 166.07 & 30.50 & 1.26 & 4.56 & 1.27 & 8.16 \\
\hline
\end{tabular}

* Significant at $\mathrm{P} \leq 0.05$ level.

(leptokurtic) (Ramadhan et al. 2018). Studies on gene interactions are needed to increase the selection efficiency in breeding programs.

In the $\mathrm{F}_{3}$ generation, plant height, plant dry weight, and pod yield per plant were positively skewed in both crosses (Figure 1), indicating complementary gene action for these traits, whereas the number of branches per plant was negatively skewed, indicating duplicate gene action. The number of pods per plant was positively skewed in cross-A and negatively skewed in cross-B (Table 2 ), indicating complementary gene interaction in cross-A and duplicate gene interaction in cross-B.

In $\mathrm{F}_{5}$ generation, the number of branches per plant, plant dry weight per plant, pod yield per plant, and the number of pods per plant were positively skewed in both crosses (Figure 1), indicating complementary gene interaction. The plant height was positively skewed in cross-A and negatively skewed in cross-B (Table 2), suggesting complementary gene interaction in cross-A and duplicate gene interaction in cross-B. Selection intensity and progress in improving population performance may be greater under complementary interaction than under duplicate interaction (Dinesh et al. 2018). For all the above traits with duplicate gene action, rapid genetic gain could be observed under mile selection
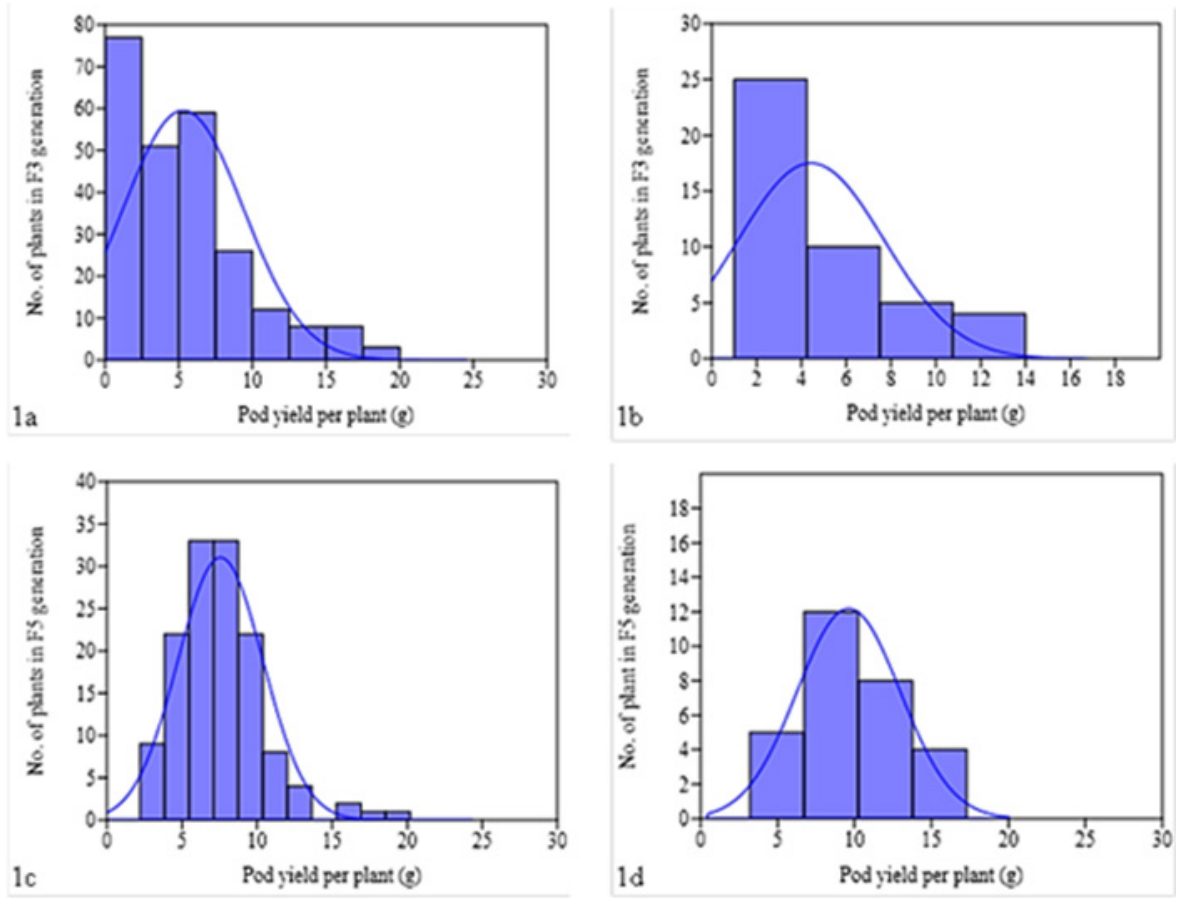

Figure 1. Frequency distribution of pod yield per plant (g), where $1 \mathrm{a}$ and $1 \mathrm{c}$ belongs to Cross-A and $1 \mathrm{~b}$ and $1 \mathrm{~d}$ belongs to Cross-B. 
Table 2. Skewness and kurtosis for yield and its component traits in $F_{3}$ and $F_{5}$ generations of two groundnut crosses

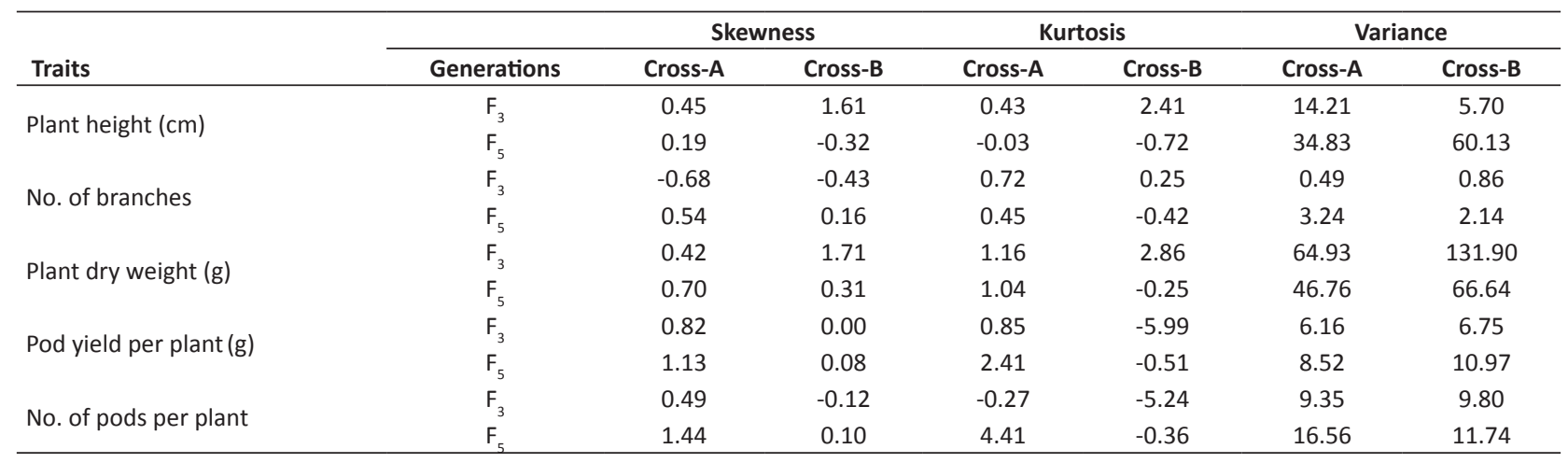

using existing variability, whereas for traits with complementary gene action, selection has to be strict for enhanced genetic gain, which is in agreement with earlier studies (Dinesh et al. 2018).

In the $F_{3}$ generation, the number of pods per plant was platykurtic, with a kurtosis value less than zero. Plant height, number of branches per plant, and plant dry weight per plant were leptokurtic, with positive kurtosis values, indicating the presence of gene interaction. These traits are therefore governed by fewer dominant genes, with the majority having an increasing effect (Nandini et al. 2017). Further, pod yield per plant had a positive kurtosis value in cross-A and a negative kurtosis in cross- $B$, indicating that it is controlled by gene interactions between many genes. Distribution of the $F_{5}$ generation showed that plant height was platykurtic in both crosses. The number of branches per plant, plant dry weight per plant, number of pods per plant, and pod yield per plant were leptokurtic in cross-A and platykurtic in cross-B, with a kurtosis value less than zero. These results are in agreement with those of Prabhu et al. (2015). Ajay et al. (2016) observed duplicate interactions for plant height, whereas pod yield per plant had complementary gene interaction in some crosses and duplicate gene interaction in other crosses of pigeon pea.

The coefficients of skewness and kurtosis decreased in $F_{5}$ compared with those in $F_{3}$ in both crosses, revealing a reduction in variability over the generation and increase in homozygosity. In addition, in the $F_{3}$ and $F_{5}$ generations, cross- $B$ had higher variance (6.75 and 10.97, respectively) compared with that in cross-A for pod yield per plant. Therefore, there is a better chance of identifying high-yielding segregants from cross-B than from cross-A during the selection of the best line in the $F_{5}$ generation.

\section{Character association}

In the $\mathrm{F}_{3}$ generation, plant height had a significant positive correlation with the number of branches per plant and plant dry weight per plant in both crosses, whereas its association with pod yield per plant and the number of pods per plant was significantly positive in the $F_{3}$ generation of cross- $A$ and negative in Cross- $B$. Pod yield per plant was significantly positively correlated with the number of pods per plant in both crosses and generations. In cross- $A$, the number of pods per plant had a significantly positive correlation with plant height in the $F_{3}$ generation as well as with the number of branches per plant and plant dry weight per plant in the $F_{5}$ generation (Table 3 ). Hence, selection could be practiced using component characters such as the number of branches and plant dry weight to increase pod yield per plant in the $\mathrm{F}_{5}$ generation (Table 3). Similar observations were made by Dinesh et al. (2017). Plant height had a significant positive association with the number of branches per plant in the $F_{3}$ generation, but the association was negative and nonsignificant in the $F_{5}$ generation of cross-A. Byadagi et al. (2018) observed a large shift in trait mean values from $F_{2}$ to $F_{3}$ generation for all traits in the three peanut crosses. This kind of shift in correlation coefficients between generations was attributed to the difference in gene complementation of linkage blocks and is an indication of the unstable nature of the breeding population (Ajay et al. 2016). It was concluded that yield contributing traits such as the number of branches per plant, pod yield per plant, and the number of pods per plant are governed by complementary gene action in both crosses. Since these characters are intercorrelated among themselves, selection of any one of these traits will result in the improvement of other traits and therefore expected to result in increased yield. The results are in agreement with 
Effect of selection response for yield related traits in early and later generations of groundnut (Arachis hypogaea L.)

Table 3. Correlation coefficient matrix among yield related characters in $F_{3}$ and $F_{5}$ generations of two groundnut crosses

\begin{tabular}{|c|c|c|c|c|c|c|c|c|c|c|c|}
\hline \multirow[b]{2}{*}{ Traits } & \multirow[b]{2}{*}{ Crosses } & \multicolumn{2}{|c|}{$\begin{array}{l}\text { Plant Height } \\
\text { (cm) }\end{array}$} & \multicolumn{2}{|c|}{ No. of Branches } & \multicolumn{2}{|c|}{$\begin{array}{l}\text { Plant dry } \\
\text { weight (g) }\end{array}$} & \multicolumn{2}{|c|}{$\begin{array}{c}\text { Pod yield } \\
\text { per plant }(\mathrm{g})\end{array}$} & \multicolumn{2}{|c|}{$\begin{array}{l}\text { No. of Pods } \\
\text { per plant }\end{array}$} \\
\hline & & $\mathrm{F}_{3}$ & $\mathrm{~F}_{5}$ & $\mathrm{~F}_{3}$ & $\mathrm{~F}_{5}$ & $\mathrm{~F}_{3}$ & $\mathrm{~F}_{5}$ & $\mathrm{~F}_{3}$ & $\mathrm{~F}_{5}$ & $\mathrm{~F}_{3}$ & $F_{5}$ \\
\hline Plant Height & Cross-A & 1 & 1 & & & & & & & & \\
\hline \multirow[t]{2}{*}{ No. of Branches } & Cross-A & $0.45^{*}$ & -0.10 & 1 & 1 & & & & & & \\
\hline & Cross-B & 0.54 & -0.01 & 1 & 1 & & & & & & \\
\hline \multirow[t]{2}{*}{ Pod yield per plant (g) } & Cross-A & $0.53 *$ & 0.10 & 0.14 & $0.43^{*}$ & 0.27 & $0.66^{*}$ & 1 & 1 & & \\
\hline & Cross-B & -0.42 & -0.14 & -0.84 & 0.11 & -0.48 & -0.24 & 1 & 1 & & \\
\hline \multirow[t]{2}{*}{ No. of Pods per plant } & Cross-A & $0.59 *$ & -0.04 & 0.29 & $0.35 *$ & 0.27 & $0.51 *$ & $0.95^{*}$ & $0.87^{*}$ & 1 & 1 \\
\hline & Cross-B & -0.30 & -0.10 & -0.77 & 0.22 & -0.34 & -0.08 & $0.98 *$ & $0.94 *$ & 1 & 1 \\
\hline
\end{tabular}

*Significant at $\mathrm{P} \leq 0.05$ level.

those of Vasanthi et al. (2015) for primary branches per plant, Hampannavar et al. (2018) for pod yield per plant, and Tirkey et al. (2018) and Zaman et al. (2011) for kernel yield.

\section{Selection of superior lines}

All the $164 \mathrm{~F}_{5}$ progenies were classified based on growth habits ( $\mathrm{SB}$ and $\mathrm{VB}$ ) to identify superior lines with higher pod yield per plant when compared with the yield of check cultivars. In the SB group, three of the 91 lines had a superior pod yield per plant than did the checks cultivars JL501 and TG37A, whereas in the VB group, two of the 73 lines had higher pod yield per plant compared with that of the check cultivar GJG32 (Table 4). Altogether, four progenies (three of $S B$ and one of $V B$ ) from cross-B were identified with a superior pod yield per plant compared with the JL501, TG37A, GJG32, and one plant (VB) from cross-A identified with pod yield per plant compared to the check GJG32 (Table 4). These lines will be further tested to confirm their yield stability over time and future use. Superior lines obtained in the segregating population after transgressive segregation had better progeny values than those of their parents in chickpea (Koseoglu et al. 2017, Ceylan et al. 2019).

\section{CONCLUSION}

The variability of traits was reduced in later generations due to increased homozygosity. Consequently, selection for characters such as pod yield per plant and number of pods per plant should be conducted in later generations such as $F_{5}$. As a result, we identified five superior progenies in the $F_{5}$ generation with higher pod yield per plant than in the respective check cultivars.

\section{ACKNOWLEDGEMENTS}

Authors are thankful to the Director, ICAR - Directorate of Groundnut Research, Junagadh, Gujarat, India for extending the facilities to conduct this research work.

\section{REFERENCES}

Ajay BC, Byregowda M, Veerakumar GN, Ganapathy KN, Meena M, Babu HP and Reena M (2016) Genetic association and frequency distribution in segregating generations derived from pigeon pea
Table 4. Pod yield and growth habit of superior $F_{5}$ progenies

\begin{tabular}{lcc}
\hline & \multicolumn{2}{c}{ Pod yield per plant $(\mathrm{g})$} \\
\cline { 2 - 3 } Genotypes & Spanish bunch & Virginia bunch \\
\hline 1 & 14.44 & - \\
2 & 14.22 & - \\
3 & 14.11 & - \\
4 & - & 17.50 \\
5 & - & 17.00 \\
TG37A (SB check) & 8.6 & - \\
JL501 (SB check) & 7.0 & - \\
GJG32 (VB check) & - & 12.0 \\
SE & 1.34 & 1.67 \\
CD (@5\%) & 3.74 & 4.66 \\
CV (\%) & 31.17 & 33.35 \\
\hline
\end{tabular}




\section{Applied Biotechnology 19: 145-152.}

Bera SK, Kamdar JH, Kasundra SV, Dash P, Maurya AK, Jasani MD, Chandrashekar AB, Manivannan N, Vasanthi RP, Dobariya KL and Pandey MK (2018) Improving oil quality by altering levels of fatty acids through marker-assisted selection of ahfad2 alleles in peanut (Arachis hypogaea L.). Euphytica 214: 162.

Bera SK, Kamdar JH, Kasundra SV, Patel SV, Jasani MD, Maurya AK, Dash P, Chandrashekar AB, Rani K, Manivannan N, Janila P, Pandey MK, Vasanthi RP, Dobariya KL, Radhakrishnan T and Varshney RK (2019) Steady expression of high oleic acid in peanut bred by marker-assisted backcrossing for fatty acid desaturase mutant alleles and its effect on seed germination along with other seedling traits. PloS One 14: e0226252.

Byadagi UR, Venkataravana P and Priyadarshini SK (2018) Genetic variability studies in $F_{2}$ and $F_{3}$ populations of three crosses of groundnut (Arachis Hypogaea L.). Journal of Pharmacognosy and Phytochemistry 7: 3139-3143.

Ceylan FO, Adak A, Sari D, Sari H and Toker C (2019) Unveiling of suppressed genes in interspecific and backcross populations derived from mutants of Cicer species. Crop and Pasture Science 70: 254-262.

Dinesh HB, Viswanatha KP, Lohithaswa HC, Pavan R and Poonam S (2017) Variability, correlation and path analysis studies in $F_{3}$ generation of cowpea [Vigna unguiculata (L.) Walp]. International Journal of Current Microbiology and Applied Sciences 6: 1420-1428.

Dinesh HB, Viswanatha KP, Lohithaswa HC, Pavan R and Poonam S (2018) Genetic association estimates using third and fourth degree statistics in early segregating generations of cowpea. International Journal of Current Microbiology and Applied Sciences 7: 867-873.

Gayathri J (2018) A trend analysis of area, production, and yield of groundnut in India. Journal of Economics 6: 15-21.

Govintharaj P, Manonmani S and Robin S (2018) Variability and genetic diversity study in an advanced segregating population of rice with bacterial blight resistance genes introgressed. Ciência e Agrotecnologia 42: 291-296.

Hammer $\varnothing$, Harper DAT and Ryan PD (2001) PAST: Paleontological statistics software package for education and data analysis. Palaeontologia Electronica 4: 9.

Hampannavar MR, Khan H, Temburne BV, Janila P and Amaregouda A (2018) Genetic variability, correlation and path analysis studies for yield and yield attributes in groundnut (Arachis hypogaea L.). Journal of Pharmacognosy and Phytochemistry 7: 870-874.

Jasani MD, Maurya AK, Dash P, Kamdar JH, Sunkad G, Mahatma MK and Bera SK (2018) Identification of peanut interspecific pre-breeding lines resistance to peanut bud necrosis disease (PBND): Field screening, morphological and biochemical parameters. International Journal of Current Microbiology and Applied Sciences 7: 1928-1939.

Kamdar JH, Jasani MD, Kasundra SV, Bera SK and Georrge JJ (2017) Recent advances on development of groundnut with high oleate traits. Bharti Publications, New Delhi, p. 493-499.
Kamdar JH, Jasani MD and Georrge JJ (2020) Development of peanut breeding lines with high oleic acid content. In Proceedings of National Conference on Innovations in Biological Sciences (NCIBS). ElsevierBiology Research Network, Rajkot, 1-4.

Kumar N, Ajay BC, Rathanakumar AL, Radhakrishnan T, Mahatma MK, Kona P and Chikani BM (2019) Assessment of genetic variability for yield and quality traits in groundnut genotypes. Electronic Journal of Plant Breeding 10: 196-206.

Koseoglu K, Adak A, Sari D, Sari H, Ceylan FO and Toker C (2017) Transgressive segregations for yield criteria in reciprocal interspecific crosses between Cicer arietinum L. and C. reticulatum Ladiz. Euphytica 213: 116.

Luz LND, Santos RCD and Melo Filho PDA (2011) Correlations and path analysis of peanut traits associated with the peg. Crop Breeding and Applied Biotechnology 11: 88-95.

Nandini C, Sujata B, Krishnappa M, Chandrashekhar A and Prabhakar (2017) Gene action, genetic parameters and association in segregating populations of two little millet (Panicum miliare L.) crosses. Green Farming 3: 523-528.

Pandey MK, Pandey AK, Kumar R, Nwosu CV, Guo B, Wright GC, Bhat RS, Chen X, Bera SK, Yuan M and Jiang H (2020) Translational genomics for achieving higher genetic gains in groundnut. Theoretical and Applied Genetics 23: 1-24.

Prabhu R, Manivannan N, Mothilal A and Ibrahim SM (2015) Nature and degree of distribution for yield and yield attributes in six backcross populations of groundnut (Arachis hypogaea L.). Plant Archives 15: 997-1001.

Prasad PV, Kakani VG and Upadhyaya HD (2010) Growth and production of groundnut. Eolss Publishers, United Kingdom, p. 1-26.

Ramadhan F, Suwarno WB, Nindita A and Aswidinnoor H (2018) Genetic analysis of panicle architecture using two $F_{2}$ population in Rice. Indonesian Journal of Agronomy 46: 1-8.

Santos AD, Ceccon G, Davide LMC, Correa AM and Alves VB (2014) Correlations and path analysis of yield components in cowpea. Crop Breeding and Applied Biotechnology 14: 82-87.

Tirkey SK, Ahmad E and Mahto CS (2018) Genetic variability and character association for yield and related attributes in groundnut (Arachis hypogaea L.). Journal of Pharmacognosy and Phytochemistry SP1: 2487-2489.

Toker C and Mutlu N (2011) Breeding for abiotic stresses. In Pratap A and Kumar J (eds) Biology and breeding of food legumes. $C A B$ International, Walingford, p. 241-261.

Vasanthi RP, Suneetha N and Sudhakar P (2015) Genetic variability and correlation studies for morphological, yield and yield attributes in groundnut (Arachis hypogaea L.). Legume Research 38: 9-15.

Vinithashri G, Manivannan N, Viswanathan PL and Selvakumar T (2019) Genetic variability, heritability and genetic advance of yield and related traits in $\mathrm{F}_{3}$ generation of groundnut (Arachis hypogaea L.). 
Effect of selection response for yield related traits in early and later generations of groundnut (Arachis hypogaea L.)

Electronic Journal of Plant Breeding 10: 1292-1297.

Woyann LG, Zdziarski AD, Baretta D, Meira D, Dallacorte LV and Benin G (2019) Selection of high-yielding, adapted and stable wheat lines in preliminary trials. Crop Breeding and Applied Biotechnology 19:
412-419.

Zaman MA, Tuhina-Khatun M, Ullah MZ, Moniruzzamn M and Alam KH (2011) Genetic variability and path analysis of groundnut (Arachis hypogaea L.). The Agriculturists 9: 29-36. 